\title{
INFLUENCE OF ZINC DEFICIENCY ON THE MINERAL COMPOSITION OF MAIZE PLANTS IN CONTRASTING SOILS
}

\author{
INFLUÊNCIA DA DEFICIÊNCIA DE ZINCO NA COMPOSIÇÃO MINERAL DE \\ PLANTAS DE MILHO EM SOLOS CONTRASTANTES
}

\section{Caio Ricardo dos Santos DOMINGUES ${ }^{1}$; Julierme Zimmer BARBOSA ${ }^{2}$; Rangel CONSALTER ${ }^{2}$; Maisa dos SANTOS ${ }^{1}$; Wiliam Magrim ADAM ${ }^{1}$; Antonio Carlos Vargas MOTTA ${ }^{3}$}

1. Mestre em Ciência do Solo, Universidade Federal do Paraná - UFPR, Curitiba, PR, Brasil; 2. Doutorando em Ciência do Solo Universidade Federal do Paraná - UFPR, Curitiba, PR, Brasil; 3. Professor, Doutor, Universidade Federal do Paraná - UFPR, Curitiba, PR, Brasil. mottaufpr@gmail.com

\begin{abstract}
In Brazil, Zn deficiency is common in soils used for maize cultivation. However, the changes in the mineral composition in plants with $\mathrm{Zn}$ deficiency have been little studied. Thus, this study aimed to evaluate the relationship between $\mathrm{Zn}$ deficiency and the mineral composition in the parts of maize plants grown under contrasting soils. Maize was grown in greenhouse conditions with increasing of $\mathrm{Zn}$ rate $\left(0,0.125,0.25,0.5\right.$ and $\left.1.0 \mathrm{mg} \mathrm{kg}^{-1}\right)$ in two soils (Ferralsol and Cambisol). After 60 days of emergence, the plant were separated into roots, stalk nodes, stalk internodes, leaves and leaf sheath, and subsequently determined the dry matter and mineral composition ( $\mathrm{P}, \mathrm{Ca}, \mathrm{Mg}, \mathrm{K}, \mathrm{Zn}, \mathrm{Fe}, \mathrm{Mn}$, $\mathrm{Cu}$ and $\mathrm{Al}$ ). Besides the symptoms commonly described for $\mathrm{Zn}$ deficiency, darkening of the stalk nodes was found (related to the preferential accumulation of Fe), and also occurred maize P deficiency in the Ferralsol. The Zn deficiency favored increasing concentrations of $\mathrm{Fe}, \mathrm{Mn}$ and $\mathrm{Al}$ in all parts of maize plants in Cambisol, whereas in Ferralsol this did not happen for any of the elements analyzed. Relations between the elements and Zn were more correlated with maize dry matter production than $\mathrm{Zn}$ concentrations in leaves, leaf sheaths and stalk nodes. In conclusion, the accumulation of minerals in maize was favored by Zn deficiency, especially for maize in Cambisol.
\end{abstract}

KEYWORDS: Zea mays L. Fe accumulation. Metal toxicity. P availability. Stalk nodes.

\section{INTRODUCTION}

An estimated half of agricultural soils used in the world are $\mathrm{Zn}$ deficient, having an average value of only $50 \mathrm{mg} \mathrm{kg}^{-1}$ as a total concentration (ALLOWAY, 2008). For highly weathered soil in Brazil, the Zn deficiency has been shown to be critical since the majority of soil parent materials were poor in $\mathrm{Zn}$ and the weathering process depleted its reservoir even more (MARQUES et al., 2004). Additionally, when these weathering acid soils were incorporated to crop production, the soil $\mathrm{pH}$ was adjusted by liming, there decrease in $\mathrm{Zn}$ availability in soil (KABATA-PENDIAS, 2011).

Maize is known as a crop sensitive to lack of $\mathrm{Zn}$, whereas availability in the soil is related to the productive potential of maize (ALLOWAY, 2008; PUGA et al., 2013). It is the second most produced crop in Brazil, and the country is the world's third largest producer (USDA, 2016). Despite this ranking, the average yield continues to be low with great potential for its improvement. This can be seen in many regions of Brazil where there is high technological level used in maize farming and favorable environment conditions, allowing yields 2 or 3 fold higher than the Brazilian national average.
To evaluate the $\mathrm{Zn}$ nutritional diagnosis, foliar analysis has been used by considering one absolute value, such as the critical level, or range of sufficiency. In some cases, however, the foliar $\mathrm{Zn}$ analysis has failed to explain the low yield despite its concentration being above the critical concentration or within the sufficiency range (HIATT; MASSEY, 1958; NAMBIAR; MOTIRAMANI, 1981). To improve the results of leaf analysis the nutritional status has considered the $\mathrm{Zn}$ balance with other nutrients. The $\mathrm{Zn}$ versus $\mathrm{Fe}$ balance has been studied as the foliar $\mathrm{Fe} / \mathrm{Zn}$ ratio and showed to be more efficient than the absolute value of the $\mathrm{Zn}$ concentration (ZARE et al., 2009). However, lack of $\mathrm{Zn}$ expressed a higher number of genes than $\mathrm{Fe}, \mathrm{Mn}$ and $\mathrm{Cu}$ and involved the higher number of proteins related to the absorption and efflux of $\mathrm{Cu}, \mathrm{Fe}, \mathrm{Mn}$ and $\mathrm{Ni}$ (WHITE, 2012).

In general, $\mathrm{Zn}$ deficiency in maize appears as a yellow striping of the leaves, under severe deficiency the plants a reddish or yellowish streak about one-third of the way from the leaf margin. Moreover, although little known, it has been reported that the stalk nodes of $\mathrm{Zn}$-deficient maize present a dark color (VITOSH et al., 1994), which can be useful for enriching the information via visual symptoms. Similar symptoms in the stalk 
were associated with high concentrations of $\mathrm{Fe}$ in soils with high availability of this element (SAYRE, 1930). Thus, considering the effects of $\mathrm{Zn}$ on the accumulation of $\mathrm{Fe}$ and other metals (NAMBIAR and MOTIRAMANI, 1981; CHILIAN et al., 2015), it is possible that: the darkness of the stalk nodes in $\mathrm{Zn}$ deficiency is related to the accumulation of $\mathrm{Fe}$ and other metals; the amount of Fe in the soil can be decisive for results.

However, even with 12 different soils, the relationship between the plant growth and $\mathrm{Zn}$ concentrations or $\mathrm{Fe} / \mathrm{Zn}$ ratio is not clear (ZARE et al., 2009). Even Nambiar and Motiramani (1981) observed relationship between production and the $\mathrm{Fe} / \mathrm{Zn}$ ratio only within each soil studied individually. This indicates that soil possibly has a strong influence on the dynamics of $\mathrm{Zn}$ uptake by the plant and, consequently, the critical levels of $\mathrm{Zn}$ and $\mathrm{Fe} / \mathrm{Zn}$ ratio.

Thus, the present study aimed to evaluate the relationship between $\mathrm{Zn}$ deficiency and the mineral composition in parts of maize plants grown under contrasting soils.

\section{MATERIAL AND METHODS}

The experiment was conducted in a plastic greenhouse (without light control and partial temperature control) in Curitiba, Paraná State, Brazil. Due to lack of light control, it is important to inform that the experiment was conducted in a period (between November and December 2013) in which the cultivation of maize is recommended in the region. The temperature control of the greenhouse had air extractors and an air humidifying system and automatically activates when the temperature reached $28^{\circ} \mathrm{C}$, remaining in operation until the temperature drops below $28^{\circ} \mathrm{C}$.

Acid soil material from a Ferrasol and a Cambisol (FAO, 2006) were collected (0-20 cm layer) in pine plantations, with no record of fertilizer or lime application. Granulometric analysis (densimeter method) showed the following results: sand, 70 and 90\%; silt, 5 and 2.5\%; clay, 25 and $7.5 \%$, respectively, Ferralsol and Cambisol. Chemical analysis of soil samples (Table 1) showed that the soils were deficient in $\mathrm{Zn}$ and, in general, presenting low fertility.

Table 1. Chemical properties of soils (S) before of liming and fertilization, from Jaguariaiva - Paraná state Brazil.

\begin{tabular}{cccccccccccccccc}
\hline $\mathrm{S}^{1}$ & $\mathrm{pH}^{2}$ & $\mathrm{Ca}^{2+}$ & $\mathrm{Mg}^{2+}$ & $\mathrm{K}^{+}$ & $\mathrm{Al}^{3+}$ & $\mathrm{H}+\mathrm{Al}^{3+}$ & $\mathrm{CEC}$ & $\mathrm{BS}$ & $\mathrm{m}$ & $\mathrm{P}$ & $\mathrm{Fe}$ & $\mathrm{Zn}$ & $\mathrm{Cu}$ & $\mathrm{Mn}$ & $\mathrm{OC}$ \\
\hline & & $---------------\mathrm{cmol}_{\mathrm{c}} \mathrm{dm}^{-3}$ & ------------- & $\%$ & $\%$ & -------- & $\mathrm{mg} \mathrm{dm}^{-3}$ & ------- & $\mathrm{g} \mathrm{dm}^{-3}$ \\
1 & 3.4 & 0.3 & 0.1 & 0.05 & 1.5 & 5.4 & 5.85 & 7.7 & 76.9 & 2.6 & 166 & 0.4 & 0.3 & 0.1 & 11.6 \\
2 & 3.9 & 0.2 & 0.1 & 0.02 & 1.0 & 5.0 & 5.32 & 6.4 & 75.7 & 2.1 & 84 & 0.4 & 0.3 & 1.8 & 11.4 \\
\hline
\end{tabular}

${ }^{1}$ Soil 1 and 2 are, respectively, Ferralsol and Cambisol. ${ }^{2} \mathrm{pH}\left(\mathrm{CaCl}_{2} 0.01 \mathrm{~mol} \mathrm{~L}^{-1}\right) ; \mathrm{Ca}^{2+}, \mathrm{Mg}^{2+}, \mathrm{Al}^{3+}$ (extracted with $\left.\mathrm{KCl} 1 \mathrm{~mol} \mathrm{~L}^{-1}\right) ; \mathrm{H}^{+}+$ $\mathrm{Al}^{3+}$ (calcium acetate $0.5 \mathrm{~mol} \mathrm{~L} \mathrm{~L}^{-1}$ extraction); organic carbon (OC) (volumetric method by potassium dichromate); $\mathrm{K}^{+}, \mathrm{P}, \mathrm{Mn}, \mathrm{Fe}, \mathrm{Cu}$ and $\mathrm{Zn}$ (Mehlich-1 extraction); Base saturation (BS); $\mathrm{Al}^{3+}$ saturation (m).

The collected soil materials were sieved by passing through a polypropylene mesh with $4 \mathrm{~mm}$ aperture before drying. Subsequently, the sieved material received lime in order to reach $70 \%$ base saturation. A mix $(1: 1)$ of pure $\mathrm{CaCO}_{3}$ and $\mathrm{MgCO}_{3}$ was applied and kept incubated for two weeks. The limed soil materials were kept covered to maintain the moisture. Note that the $\mathrm{pH}$ increase with liming reduces the availability of $\mathrm{Zn}$ and $\mathrm{Mn}, \mathrm{Fe}, \mathrm{Cu}, \mathrm{Ni}$ and B. Thus, liming likely accentuated the lack of $\mathrm{Zn}$ in Ferralsol and Cambisol.

After the incubation period, $6 \mathrm{~kg}$ of dried soil materials was weight and put in vases for a total of 40 vases. Analytic reagents were used to prepare a solution and this was applied on the soil surface in each vase in the following amount and source: 200 $\mathrm{mg} \mathrm{kg}{ }^{-1}$ of $\mathrm{N}, \mathrm{P}_{2} \mathrm{O}_{5}$ and $\mathrm{K}_{2} \mathrm{O} ; 0.5 \mathrm{mg} \mathrm{kg}^{-1} \mathrm{~B}, 1 \mathrm{mg}$ $\mathrm{kg}^{-1}$ of $\mathrm{Cu}$ and $0.2 \mathrm{mg} \mathrm{kg}^{-1}$ Mo in the form of urea, monocalcium phosphate, potassium chloride, boric acid, sodium molybdate and copper chloride, respectively.

After the nutrient application, the treatments were performed by adding $0 ; 0.125 ; 0.25 ; 0.5$ and $1.0 \mathrm{mg} \mathrm{kg}{ }^{-1}$ of $\mathrm{Zn}$ as analytic $\mathrm{ZnCl}_{2}$. The lower $\mathrm{Zn}$ levels (up to $0.5 \mathrm{mg} \mathrm{kg}^{-1}$ ) were chosen to obtain different stages of deficiency (moderate to severe). However, the highest level was chosen to provide the plants with conditions without severe deficiency.

Each experimental unit consisted of a glazed vase filled with soil. The soil material was mixed after each procedure (sieving, liming, incubation, nutrients application and $\mathrm{Zn}$ application) in order to maintain homogeneity. The moisture was also determined after sieving, incubation, and nutrients application in order to calculated dry weight base equivalent application.

Five seeds of Agroceres F1 Hybrid RR maize were sown and 10 days after emergence thinning was conducted, maintaining only two 
seedlings per vase. Irrigation of the vases was performed daily as needed, using deionized water. At the end of the experiment, 60 days after seedling emergence plant height was determined. The shoot was cut at $1 \mathrm{~cm}$ from the soil surface and brought to the lab where the shoots were separated into stalks and leaves. The stalk was laid on a wooded table and longitudinal cut was performed in the middle in order to have an internal view of the stalk nodes and internodes. Photographs were taken (Fujifilm A220 camera) of the plant with the inside of the stalk exposed. The stalk was cut again into nodes, internodes and sheath leaves.

The soil with roots was pulled out of the vase and was put on a $4 \mathrm{~mm}$ sieve and gently handles to release the soil. After most of the soil was lost a spray of pressurized water was applied. In the laboratory, roots were cleaned again under running water to remove the small soil particles from inside the root mass. Finally, the root was immersed in $\mathrm{NaOH} 1.25 \mathrm{~mol} \mathrm{~L}^{-1}$ for 15 minutes and again under deionized water. The root and shoot fractions then were dried at $60{ }^{\circ} \mathrm{C}$ for 48 hours to obtain the dry matter production which was ground in Willey mill and passed through a $1 \mathrm{~mm}$ sieve.

The chemical analysis of the maize fractions (roots, stalk nodes, stalk internodes, leaves and leaf sheaths) was performed by dry digestion; a subsample of $1 \mathrm{~g}$ was calcined in a porcelain crucible in muffle furnace at $500^{\circ} \mathrm{C}$ for 3 hours. After cooling of the crucibles, the ash was digested with $3 \mathrm{~mol} \mathrm{~L}^{-1}$ $\mathrm{HCl}$ and the crucibles remained in the muffle at $500^{\circ} \mathrm{C}$ for 3 more hours. Afterwards, $10-\mathrm{ml}$ of $3 \mathrm{~mol}$ $\mathrm{L}^{-1} \mathrm{HCl}$ was then added and the crucibles remained for 10 minutes on a hot plate at $70{ }^{\circ} \mathrm{C}$. The digestion solutions were filtered in filter paper and the extracts collected in 100-ml volumetric flasks. To gauge the volumetric flasks, deionized water was used. The following were determined in the obtained extracts: $\mathrm{K}$ with flame emission spectrometer (Digimed, MD-62); P with UV-VIS spectrometer (Bel Photonics, SP2000), colorimetry via ammonium molybdate-vanadate; $\mathrm{Ca}, \mathrm{Mg}, \mathrm{Fe}$, $\mathrm{Mn}, \mathrm{Zn}, \mathrm{Cu}$, and $\mathrm{Al}$ with atomic absorption spectrometer (Varian, AA240FS). The difference (\%) of $\mathrm{Fe}, \mathrm{Mn}, \mathrm{Cu}, \mathrm{Zn}, \mathrm{P}, \mathrm{K}, \mathrm{Ca}$ and $\mathrm{Mg}$ in the stalk nodes compared to stalks internodes was obtained based on element concentration and content.

The experimental was arranged in a completely randomized design with $2 \times 5$ factorial ( 2 soils and $5 \mathrm{Zn}$ rates), with four replications, and each experimental unit consisted of a vase with two plants. However, for the results of stalk internodes a factorial $2 \times 4$ was used, because the plant growth was so reduced under the absence of $\mathrm{Zn}$ that it was not possible to obtain enough mass to run analysis for this treatment. For data analysis we performed variance (ANOVA). Where the ANOVA result was significant, the data were analyzed by regression for $\mathrm{Zn}$ rates and by Least Significant Difference (LSD) test to compare the soils. Pearson correlations between some data were also obtained. For all tests, the minimum level of 5\% significance level was adopted.

\section{RESULTS AND DISCUSSION}

Symptoms of nutritional deficiency associated with $\mathrm{Zn}$ were observed in maize plants for both soils. In the control, with the absence of $\mathrm{Zn}$, the seedling had reduced growth and necrosis of all leaves in Cambisol, while in Ferralsol it was observed interveinal chlorosis in new leaves and necrotic spots on the intermediate leaves. These results indicate that the Cambisol Zn deficiency was more severe, leading to leaf necrosis (BROADLEY et al., 2012). A larger plant was observed when 0.125 and $0.250 \mathrm{mg} \mathrm{kg}^{-1}$ were used, compared to the control. The symptoms were characterized by interveinal chlorosis on young leaves with subsequent general chlorosis of these leaves, stiff leaves and internode growth reduction. Although still being deficient, the two lower $\mathrm{Zn}$ rates improved maize nutrition, including Cambisol where plants showed no necrosis in the leaves.

At the $0.5 \mathrm{mg} \mathrm{kg}^{-1} \mathrm{Zn}$ rate only interveinal chlorosis in new leaves was observed in the Cambisol, whereas in Ferralsol these symptoms were also observed at the dose of $1.0 \mathrm{mg} \mathrm{kg}^{-1}$. In addition, in Ferralsol, regardless of the amount of $\mathrm{Zn}$ added, a purple color on the old leaves was observed. Therefore, in Ferralsol there is simultaneous $\mathrm{Zn}$ and $\mathrm{P}$ deficiency, which must be kept in mind to understand the possible changes in elemental composition. When the stalk was split in the middle by a longitudinal cut, the node internal areas were dark under Zn deficiency (Figure 1), for both soils, but in Ferralsol plants present this symptom at all $\mathrm{Zn}$ rates. Therefore, when $\mathrm{Zn}$ deficiency symptoms were detected on leaves, there also occurred darkening of the stalk nodes, indicating that the nodes can be used as additional tools for visual diagnosis, corroborating with Vitosh (1994). 

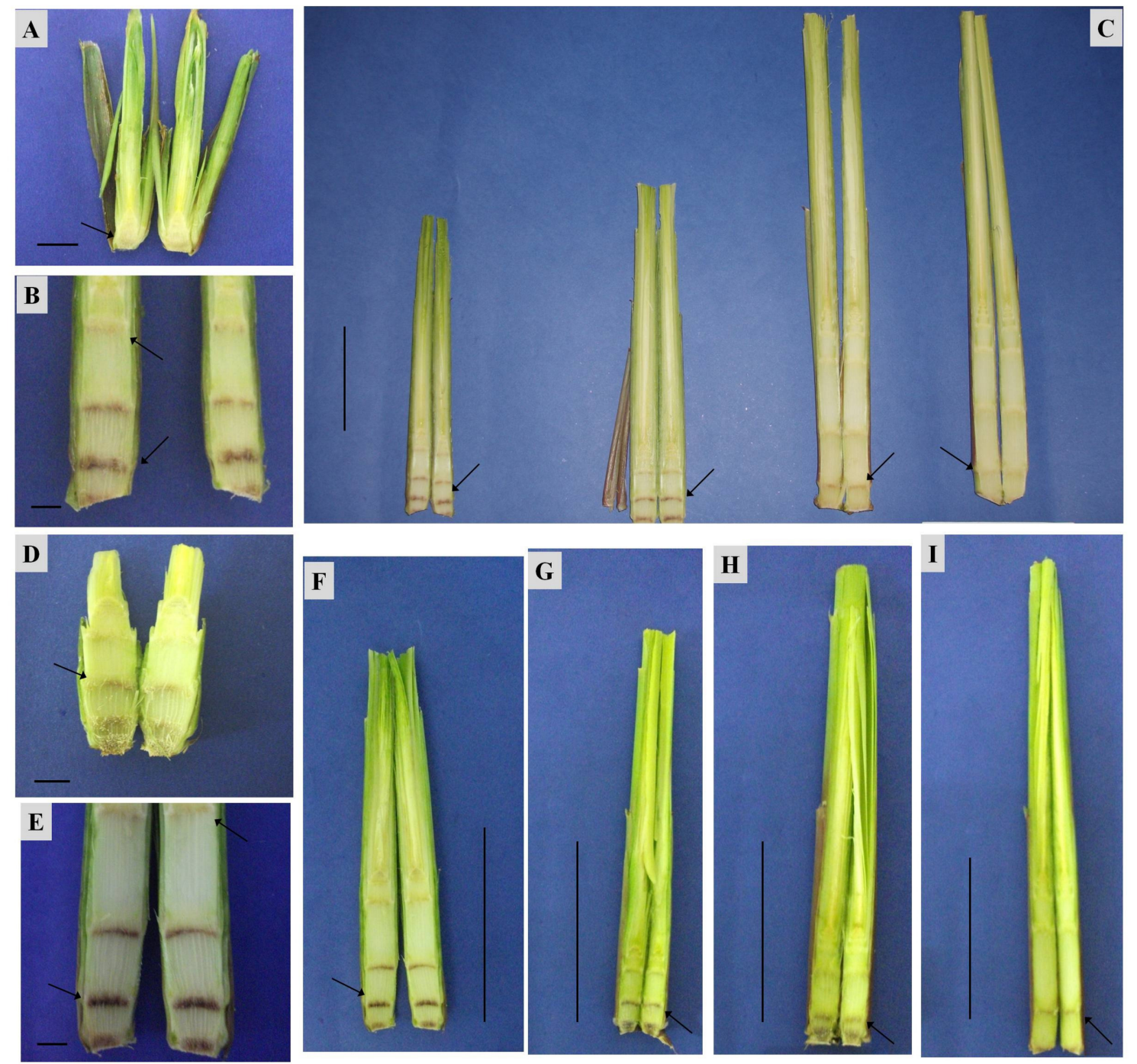

Figure 1. Cut stalk of maize grown with increasing $\mathrm{Zn}$ rates. For Cambisol: $\mathrm{A}=$ without $\mathrm{Zn}$ addition; $\mathrm{B}=$ addition of $0.125 \mathrm{mg} \mathrm{kg}^{-1} \mathrm{Zn} ; \mathrm{C}=$ increasing $\mathrm{Zn}$ rate addition. For Ferralsol: $\mathrm{D}=$ without $\mathrm{Zn}$ addition; $\mathrm{E}$ and $\mathrm{F}=$ addition of $0.125 \mathrm{mg} \mathrm{kg}^{-1} \mathrm{Zn} ; \mathrm{G}=$ addition of $0.25 \mathrm{mg} \mathrm{kg}^{-1} \mathrm{Zn} ; \mathrm{H}=$ addition of $0.5 \mathrm{mg} \mathrm{kg}^{-1} \mathrm{Zn}$; I = addition of $1.0 \mathrm{mg} \mathrm{kg}^{-1} \mathrm{Zn}$. Bars of $1 \mathrm{~cm}(\mathrm{~A}, \mathrm{~B}, \mathrm{D}$ and $\mathrm{E})$ and $10 \mathrm{~cm}(\mathrm{C}, \mathrm{F}, \mathrm{G}, \mathrm{H}$ and I).

The dry matter results confirmed the condition of high $\mathrm{Zn}$ deficiency for both soils (Figure 2). But, higher growth and $\mathrm{Zn}$ response were obtained for Cambisol compared to Ferrasol, which differs in the two higher $\mathrm{Zn}$ rates for roots, leaves, sheath leaves and total dry matter, and the three higher $\mathrm{Zn}$ rates for nodes and internodes of the stalks. Our results confirm an earlier observation that $\mathrm{Zn}$ promotes plant growth by enhancing hormonal and protein syntheses since it is required to form tryptophan amino acid that is a precursor of indole acetic acid (BROADLEY et al., 2012). Positive responses to $\mathrm{Zn}$ application have been obtained in several studies, which report superiority in the production of dry matter in maize (KANAI et al., 2009; ZARE et al., 2009) and wheat (ALAM; SHEREEN, 2002; ZHAO et al., 2011).
The difference in response between the soils to the $\mathrm{Zn}$ application may be associated to variation in $P$ availability, which changed the $P$ concentrations in maize leaves (Table 2). This difference is due to the higher clay content in Ferralsol (25\%) compared to Cambisol (7.5\%). Furthermore, due to its more advanced weathering degree, the Ferralsol probably contains more oxides in the clay fraction. Therefore, considering the ability of these minerals to adsorb the P (GÉRARD, 2016); there was a likely lower $P$ availability in Ferralsol due to higher adsorption of this element in the soil mineral fraction. Thus, although phosphate fertilization was conducted, it is likely that $\mathrm{P}$ fixation made less $\mathrm{P}$ available to the plants in Ferralsol. 

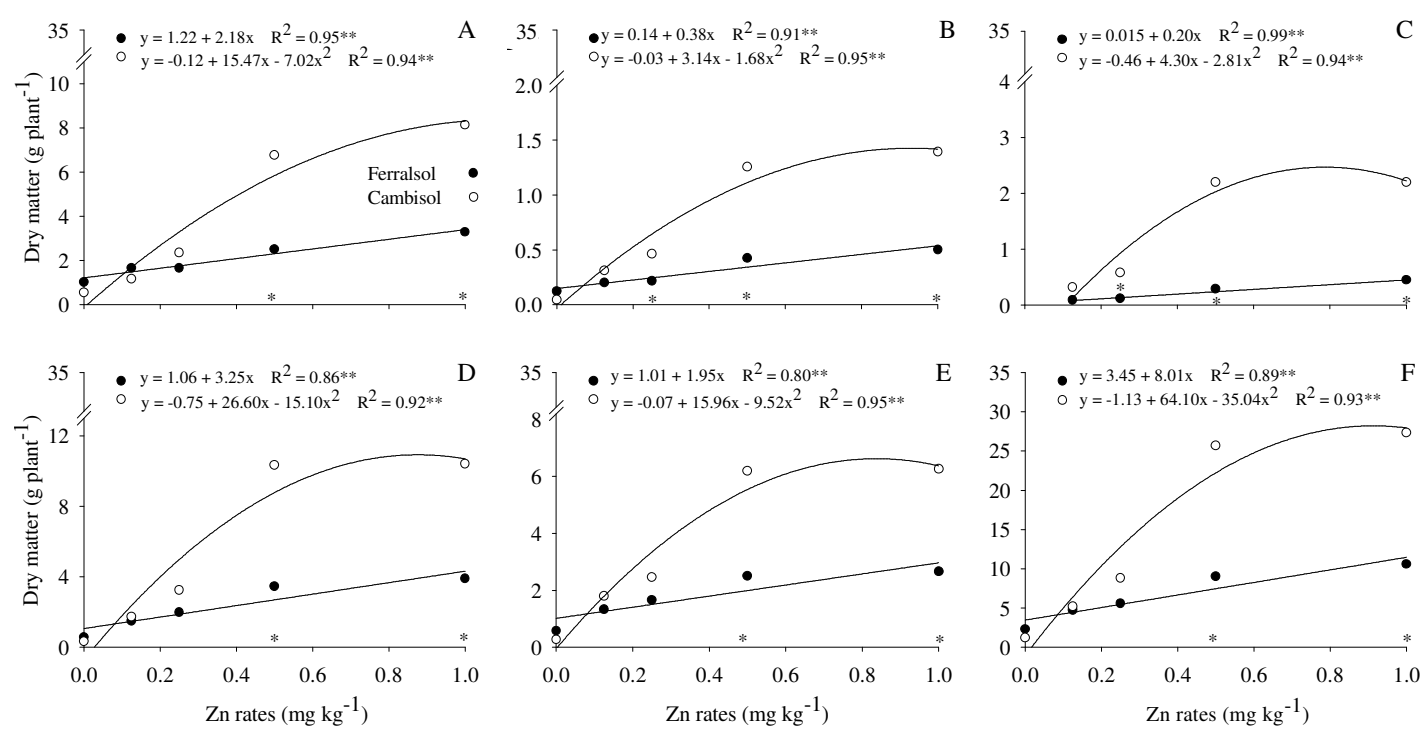

Figure 2. Dry matter of roots (A), stalk nodes (B), stalk internodes (C), leaves (D), sheath leaves (E) and total (F) of maize grown in Ferrasol and Cambisol with increasing $\mathrm{Zn}$ rates. $* *=$ Significant at $1 \%$ for $\mathrm{Zn}$ rates; $*=$ difference (significant at $5 \%$ by LSD test) between soils.

Table 2. Concentration of $\mathrm{K}, \mathrm{Ca}, \mathrm{Mg}$ and $\mathrm{P}\left(\mathrm{g} \mathrm{kg}^{-1}\right)$ in leaves of maize grown in two soils with application of $\mathrm{Zn}$ rates

\begin{tabular}{|c|c|c|c|c|c|c|c|c|c|c|}
\hline & \multirow{2}{*}{ Soil $^{1}$} & \multirow{2}{*}{ Soil $^{2}$} & \multirow{2}{*}{ Soil x Zn } & \multicolumn{5}{|c|}{$\mathrm{Zn}$ rates $\left(\mathrm{mg} \mathrm{kg}^{-1}\right)$} & \multirow{2}{*}{ Equation } & \multirow{2}{*}{$\mathbf{R}^{2}$} \\
\hline & & & & $\mathbf{0 . 0}$ & 0.125 & 0.25 & 0.5 & 1.0 & & \\
\hline \multirow{2}{*}{$\mathrm{K}$} & 1 & & & $20.2^{*}$ & 23.8 & 25.0 & $22.4^{*}$ & $18.8^{*}$ & $y=22.1$ & ns \\
\hline & 2 & ns & $*$ & 26.8 & 26.3 & 24.5 & 13.4 & 11.1 & $y=27.6-18.1 x$ & $0.82 * *$ \\
\hline \multirow{2}{*}{$\mathrm{Ca}$} & 1 & \multirow{2}{*}{ * } & \multirow{2}{*}{ ns } & 11.5 & 6.8 & 7.1 & 5.5 & 4.3 & $y=10.4-16.4 x+10.4 x^{2}$ & $0.84 * *$ \\
\hline & 2 & & & 10.6 & 5.8 & 4.9 & 3.4 & 2.9 & $y=9.7-21.6 x+15.2 x^{2}$ & $0.90 * *$ \\
\hline \multirow{2}{*}{$\mathrm{Mg}$} & 1 & \multirow[b]{2}{*}{ ns } & \multirow[b]{2}{*}{ * } & $7.7 *$ & 5.4 & 5.4 & 4.9 & 4.4 & $y=7.1-7.8 x+5.2 x^{2}$ & $0.89 * *$ \\
\hline & 2 & & & 10.4 & 5.3 & 5.3 & 4.1 & 3.5 & $y=9.2-18.2 x+12.8 x^{2}$ & $0.81 * *$ \\
\hline \multirow{2}{*}{$\mathrm{P}$} & 1 & \multirow{2}{*}{$*$} & \multirow{2}{*}{ ns } & 4.0 & 5.5 & 3.2 & 1.6 & 0.9 & $y=4.5-4.2 x$ & $0.74 * *$ \\
\hline & 2 & & & 7.5 & 9.2 & 8.8 & 2.1 & 1.5 & $y=8.8-8.2 x$ & $0.72 * *$ \\
\hline
\end{tabular}

${ }^{1}$ Ferralsol $=1$, Cambisol $=2 ;{ }^{2}$ not significant (ns) or significant at 5\% (LSD test) for soil and interaction soil versus Zn rates, and $* *$ significant at $1 \%$ for $\mathrm{Zn}$ rates.

In general, a reduction of element concentrations in leaves, leaf sheaths, internodes and stalk nodes of the maize stem in response to the $\mathrm{Zn}$ addition. However, the stabilization thereof, by the application of $1 \mathrm{mg} \mathrm{kg}^{-1} \mathrm{Zn}$, or a stable $\mathrm{Zn}$ supply condition, is clear (Figure 3; Table 3). The roots showed variable results among the analyzed elements and soils. Moreover, the variations between soils occurred mainly $\mathrm{Fe}$ and $\mathrm{Mn}$.

The influence of $\mathrm{Zn}$ on nutrients and $\mathrm{Al}$, especially when it was deficient (Figure 3; Table 3), could be related to complex interactions between plant physiology and soil environment. Many changes in plant metabolism, root exudation and rhizosphere could be expected. The reduction of the concentrations of elements in maize (mainly leaves, leaf sheaths and stalk nodes) in response to the addition of $\mathrm{Zn}$ is related to: (i) the possibility that more phytosiderophores exudation in the rhizosphere of maize occurred under a $\mathrm{Zn}$ deficiency condition, as highlighted by Römheld (1991) for grasses, favoring the complexation and absorption of less available forms of soil $\mathrm{Zn}$. However, phytosiderophores can increase the acquisition of other micronutrients such as $\mathrm{Mn}$ and $\mathrm{Cu}$, and especially $\mathrm{Fe}$. 

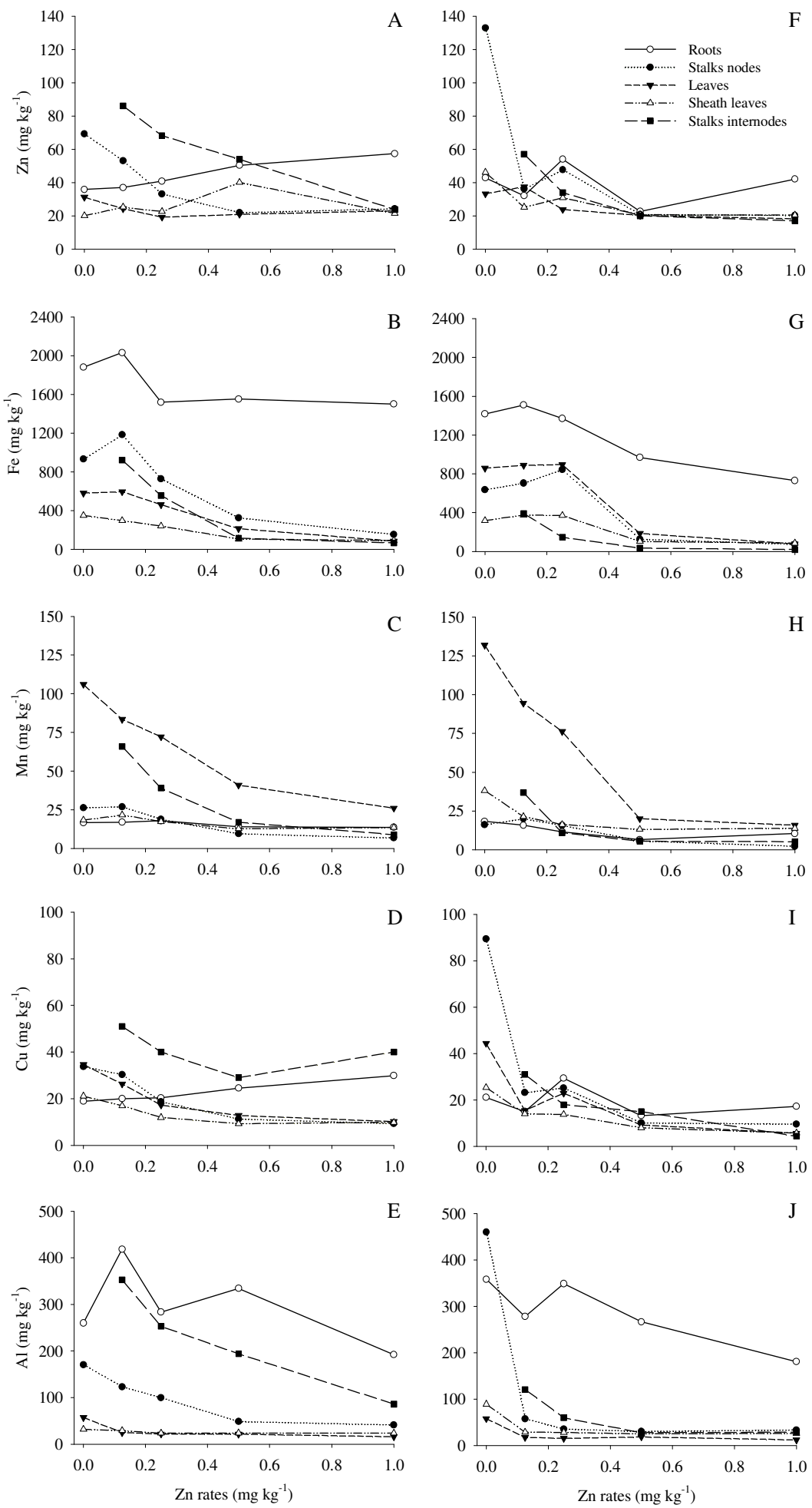

Figure 3. Concentrations of $\mathrm{Zn}(\mathrm{A}, \mathrm{F}), \mathrm{Fe}(\mathrm{B}, \mathrm{G}), \mathrm{Mn}(\mathrm{C}, \mathrm{H}), \mathrm{Cu}(\mathrm{D}, \mathrm{I})$ and $\mathrm{Al}(\mathrm{E}, \mathrm{J})$ in the roots, stalk nodes, stalk internodes, leaves and leaf sheaths of maize grown in Ferrasol (A-E) and Cambisol (F-J) with increasing $\mathrm{Zn}$ rates. 
Table 3. Effect of soil, $\mathrm{Zn}$ rates (with equation and determination coefficient $-\mathrm{R}^{2}$ ) and interaction soil versus $\mathrm{Zn}$ rates in concentration of elements $(\mathrm{Zn}, \mathrm{Fe}, \mathrm{Mn}, \mathrm{Cu}$ and $\mathrm{Al}$ ) for maize grown in Ferralsol and Cambisol

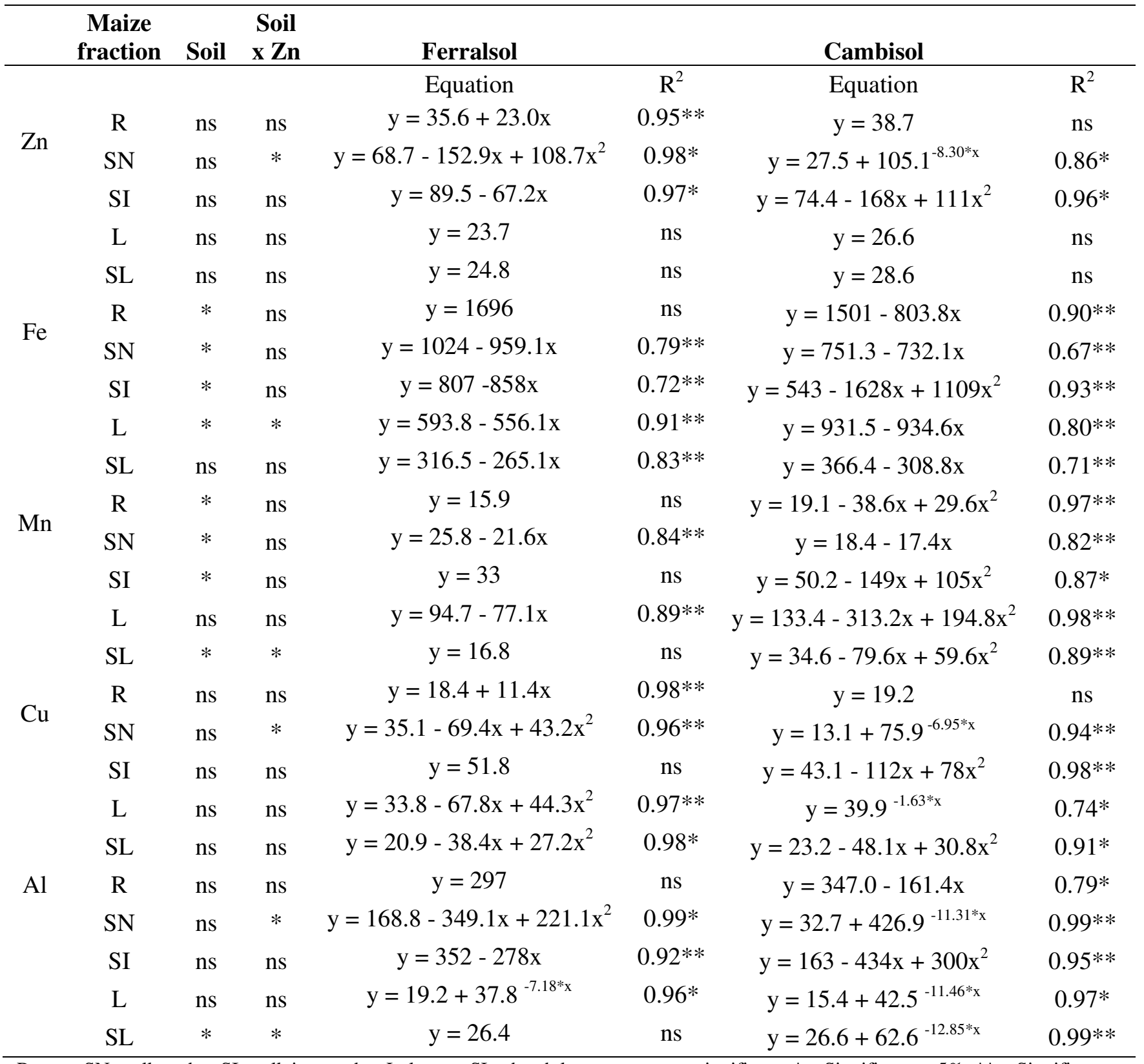

R, root; SN, stalk nodes; SI, stalk internodes; L, leaves; SL, sheath leaves; ns = not significant; * = Significant at 5\%; ** = Significant at $1 \%$.

In addition, the reverse may also occur, for example, the lack of $\mathrm{Fe}$ increases $\mathrm{Zn}$ levels in maize, as evidenced by Kanai et al. (2009). (ii) the maize also boots the release of other chemicals in the rhizosphere, such as organic acids, enzymes, amino acids, gaseous molecules and $\mathrm{H}^{+}$and $\mathrm{OH}^{-}$; that vary with nutritional status and may increase or reduce the acquisition of certain elements (BADRI; VIVANCO, 2009). (iii) the changes in $\mathrm{C}$ deposition via maize roots modify the microbial community in the rhizosphere and thus may indirectly be favored microorganisms that present an element solubilizing capacity (MARSCHNER, 2012). (iv) the occurrence of competition between ionic forms during uptake, interference with chelation process during uptake and translocation and the competitive inhibition during unloading in the xylem may also affect $\mathrm{Zn}$ interaction with other elements (WHITE, 2012; CHILIAN et al., 2015).

In soil with higher $\mathrm{Fe}$ concentrations (Ferralsol) high concentrations of $\mathrm{Fe}$ were registered in the first fractions (roots, internode and stem node) of maize plants. However, the leaf $\mathrm{Fe}$ concentrations were lower in Ferralsol (Figure 3; Table 3). Thus, 
the soil was important to explain the variations of $\mathrm{Fe}$ in the roots, internodes and stalk nodes. However, variations in $\mathrm{Fe}$ in leaves indicate that the mechanisms related to Fe transport (BROADLEY et al., 2012) were more important than their availability in soil. Furthermore, high $\mathrm{Fe}$ concentrations in the first fractions of maize may have been favored by $\mathrm{P}$ deficiency in Ferralsol, considering that the $\mathrm{P}$ deficiency favors the exudation of low molecular weight organic acids (BADRI; VIVANCO, 2009). Compared to Ferralsol (Figure 3; Table 3), plants grown in Cambisol had lower Mn concentrations in stalk nodes, while concentrations in root, stem internodes and leaf sheath were higher. For Cambisol, higher Mn concentrations in most plant fractions indicates that they may be due to higher initial concentrations of Mn in this soil (Table 1), similar to what was observed for Fe. Furthermore, Cambisols present higher concentration of amorphous fractions or low
DOMINGUES, C. R. S. et al.

crystallinity, with higher possibility of being solubilized by organic acids released by the roots. However, the more general difference between $\mathrm{Mn}$ and $\mathrm{Fe}$ was the distribution of elements in the tissues because the Mn showed higher concentrations in the leaves and stalk internodes, whereas the Fe showed higher concentrations in root and stalk nodes.

The $\mathrm{Fe}$ showed a natural trend to accumulate in the roots. However, in the aerial part, the $\mathrm{Fe}$ showed a natural trend to accumulate in the stalk nodes, since it was the only element for which the concentration in the nodes was always higher than in internodes, regardless of the soil and the $\mathrm{Zn}$ rates (Figure 3; Table 3). This was confirmed via the concentration of $\mathrm{Fe}$ in stalk nodes being $40 \%$ to $470 \%$ (based on concentration) and $175 \%$ to $700 \%$ (based on content) higher than in the internodes (Figure 4).
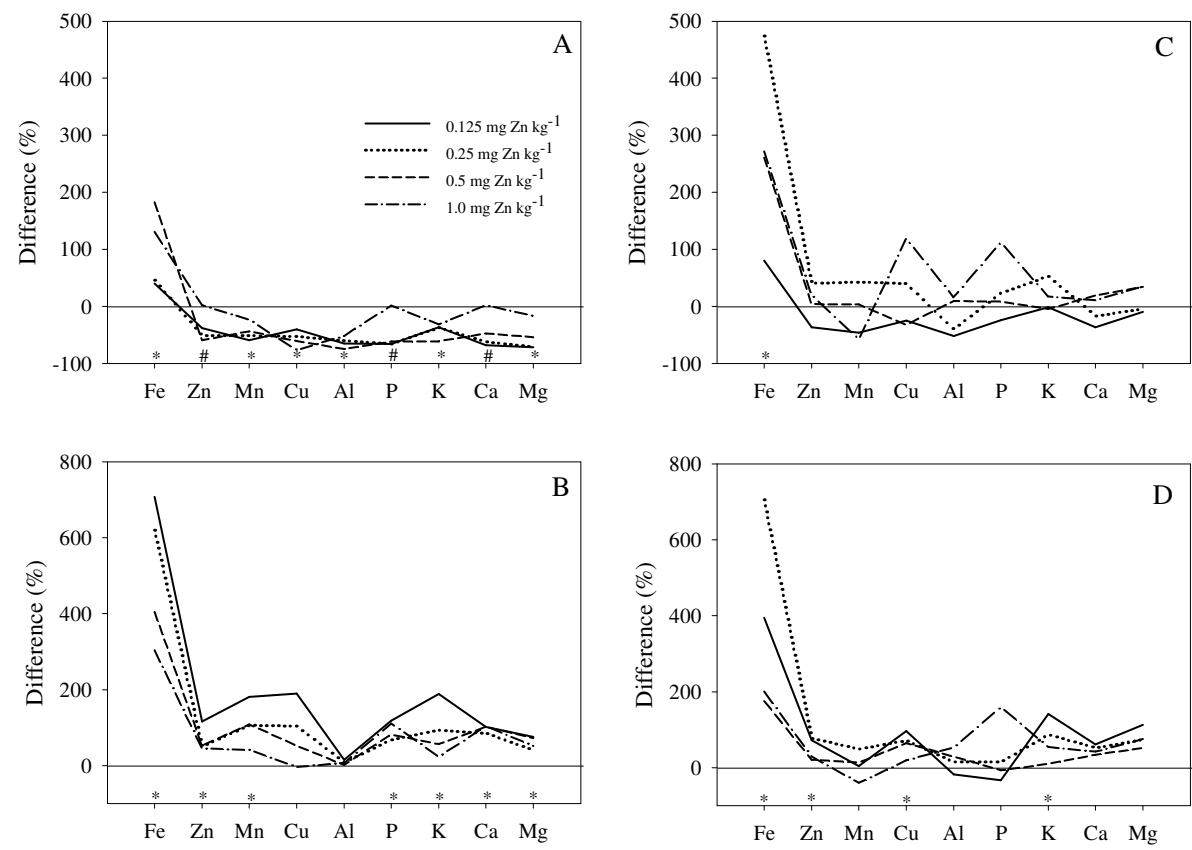

Figure 4. Difference (\%) of $\mathrm{Fe}, \mathrm{Mn}, \mathrm{Cu}, \mathrm{Zn}, \mathrm{P}, \mathrm{K}, \mathrm{Ca}$ and $\mathrm{Mg}$ in the stalk nodes in comparison to stalk internodes of maize grown in Ferralsol (A and $B$ ) and Cambisol (C and D) with increasing Zn rates. Based on concentration $(\mathrm{A}$ and $\mathrm{C})$ and content $(\mathrm{B}$ and $\mathrm{D}) . *$ All $\mathrm{Zn}$ rates present significant difference (LSD test; $\mathrm{p}<0.05)$. \# Only three $\mathrm{Zn}$ rates.

Corroborating with the results of this study, Brown and Holmes (1955) using radioactive Fe, observed its preferential accumulation in maize stalk nodes compared to internodes, and in $\mathrm{Cu}$ deficient plants this buildup was intensified. The most probable explanation for this fact was presented by Shane et al. (2000) who indicated that for maize, vascular bundles were in axial internodes, while stalk nodes were in axial and transversal. This made the node areas highly congested with vascular bundles and approximately $97 \%$ of the axial vessels being interrupted by end walls in the area. In addition, these end walls have a low porosity $(<20$ $\mathrm{nm}$ ) on the basis of nodes and between axial and transverse vessels within the nodes, acting as a filter. In the stalk of maize plants grown in soil with 
high concentrations of available Fe, Sayre (1930) observed accumulation of this element in the form of dark-colored crystals, especially in the nearby cells of the vascular bundles. McClean et al. (2001) reported $\mathrm{Fe}$ accumulation in leaves and stems of grass (Festuca spp.) as crystals of magnetite $\left[\mathrm{Fe}_{3} \mathrm{O}_{4}\right], \varepsilon-\mathrm{Fe}_{2} \mathrm{O}_{3}$, hematite $\left[\alpha-\mathrm{Fe}_{2} \mathrm{O}_{3}\right]$ and calcium ferrate hexahydrate $\left[3 \mathrm{CaO} \cdot \mathrm{Fe}_{2} \mathrm{O}_{3} \cdot \mathrm{H}_{2} \mathrm{O}\right]$. Similarly, Rodríguez et al. (2005) found Fe-crystals inside Imperata cylindrica (L.) Rauschel (grass) cultivated in soil with high $\mathrm{Fe}$ availability, corresponding to $50 \%$ of jarosite $\left[\mathrm{KFe}_{3}\left(\mathrm{SO}_{4}\right)_{2}(\mathrm{OH})_{6}\right]$. Thus, it is possible that the higher $\mathrm{Fe}$, resulting from $\mathrm{Zn}$ deficiency (Figure 2), may also provide conditions for the $\mathrm{Fe}$ precipitation and the consequent darkening of nodes. In the case of Ferralsol, it found that the darkening of the stalk nodes occurred even with the addition of $\mathrm{Zn}$ (although to a lesser degree), which should have been favored by the deficiency of $\mathrm{P}$ and higher Fe levels in stalk nodes for this soil.

Contrary to that expected and observed for plant growth, the leaf $\mathrm{Zn}$ concentration did not change as result of its addition (Figure 3A, F; Table 3). A difficulty to associate $\mathrm{Zn}$ leave concentration and maize yield was observed by Ritchey et al. (1986) who applied $3 \mathrm{~kg} \mathrm{ha}^{-1}$ of $\mathrm{Zn}$ and observed a twofold yield increase with no significant change in
$\mathrm{Zn}$, three years in row. The same problem has been observed by Hiatt and Massey (1958) under controlled conditions, who found severe, middle and no deficiency symptoms for maize leaves with 18, 9 and $16 \mathrm{mg} \mathrm{kg}^{-1} \mathrm{Zn}$, without, low and normal $\mathrm{Zn}$ supply via nutritive solution. Zare et al. (2009) observed that variations in $\mathrm{Zn}$ concentrations in maize leaves, with and without deficiency, were dependent on the soil type, allowing high or low levels in deficient plants.

Correlations between the $\mathrm{Zn}$ and matter production (Table 4) failed (leaves) or showed negative values, as in stalk nodes ( $\mathrm{r}=-0.51)$, confirming the results presented above (Table 3 ). Thus, accumulation of $\mathrm{Zn}$ with in stalk nodes can indicate $\mathrm{Zn}$ deficiency. However, the balance between the $\mathrm{Zn}$ and other elements, represented by element/Zn ratios $(\mathrm{P} / \mathrm{Zn}, \mathrm{K} / \mathrm{Zn}, \mathrm{Ca} / \mathrm{Zn}, \mathrm{Mg} / \mathrm{Zn}$, $\mathrm{Cu} / \mathrm{Zn}, \mathrm{Mn} / \mathrm{Zn}, \mathrm{Fe} / \mathrm{Zn}$ and $\mathrm{Al} / \mathrm{Zn}$ ) showed better than $\mathrm{Zn}$ alone in leaves, sheath leaves or stalk nodes. However, it is worth noting that the best results using element/Zn ratio occurred when the leaves were used as diagnostic tissue. These results corroborated with the proposal of Nambiar and Motiramani (1981) and Zare et al. (2009), who indicated the ratios as an alternative when $\mathrm{Zn}$ concentration in leaves fails to explain plant growth.

Table 4. Pearson correlation for dry matter (DM) versus $\mathrm{Zn}$ concentrations or element/Zn ratio in leaves or stalk nodes of maize grown in Ferrasol and Cambisol with increasing $\mathrm{Zn}$ rates

\begin{tabular}{|c|c|c|c|c|c|c|c|c|c|}
\hline & $\mathrm{Zn}$ & $\mathrm{P} / \mathrm{Zn}$ & $\mathrm{K} / \mathrm{Zn}$ & $\mathrm{Ca} / \mathrm{Zn}$ & $\mathrm{Mg} / \mathrm{Zn}$ & $\mathrm{Cu} / \mathrm{Zn}$ & $\mathrm{Mn} / \mathrm{Zn}$ & $\mathrm{Fe} / \mathrm{Zn}$ & $\mathrm{Al} / \mathrm{Zn}$ \\
\hline & \multicolumn{9}{|c|}{ All data (Ferralsol + Cambisol) } \\
\hline Leaves & -0.33 & -0.02 & -0.14 & -0.31 & -0.09 & -0.48 & $-0.76^{*}$ & $-0.53 *$ & -0.33 \\
\hline Sheath leaves & -0.16 & -0.24 & $-0.62 *$ & 0.31 & 0.01 & $-0.62 *$ & -0.07 & $-0.53 *$ & 0.03 \\
\hline Stalk nodes & $-0.51 *$ & 0.07 & -0.14 & 0.27 & $\begin{array}{c}0.70 * \\
\text { Ferralsol }\end{array}$ & -0.25 & -0.36 & -0.42 & 0.17 \\
\hline Leaves & -0.29 & $-0.57 *$ & -0.06 & $-0.52 *$ & -0.38 & $-0.62 *$ & $-0.73^{*}$ & $-0.64 *$ & $-0.59 *$ \\
\hline Sheath leaves & 0.29 & 0.22 & $-0.50 *$ & -0.40 & -0.45 & $-0.75^{*}$ & 0.09 & $-0.73^{*}$ & 0.31 \\
\hline Stalk nodes & $-0.53 *$ & 0.17 & $0.56^{*}$ & 0.40 & $\begin{array}{c}0.76^{*} \\
\text { Cambisol }\end{array}$ & -0.30 & -0.42 & -0.45 & 0.09 \\
\hline Leaves & -0.46 & -0.28 & -0.03 & -0.11 & 0.01 & -0.46 & $-0.88^{*}$ & $-0.72 *$ & 0.33 \\
\hline Sheath leaves & $-0.54 *$ & -0.46 & $-0.58^{*}$ & 0.18 & 0.36 & $-0.85^{*}$ & -0.15 & $-0.60 *$ & -0.06 \\
\hline Stalk nodes & $-0.65^{*}$ & 0.06 & -0.29 & 0.19 & $0.64 *$ & -0.35 & -0.40 & -0.37 & 0.00 \\
\hline
\end{tabular}

$*=$ significant at $1 \%$.

For leaves, the $\mathrm{Mn} / \mathrm{Zn}(\mathrm{r}=-0.76)$ and $\mathrm{Fe} / \mathrm{Zn}$ $(r=-0.53)$ ratios showed to be the best correlations to explain maize growth (Table 4). Since $\mathrm{Zn}$ application presented a large decrease in Fe in the plant tissue under Zn lack (RITCHEY et al., 1986; CHILIAN et al., 2015), the Fe/Zn ratio in maize 
leaves has been proposed as a diagnostic tool (NAMBIAR and MOTIRAMANI, 1981). The same authors and Zare et al. (2009) suggested that ratio values between 2 and 6 for $\mathrm{Fe} / \mathrm{Zn}$ were the most suitable for maize cultivation. However, the highest correlation was obtained by $\mathrm{Mn} / \mathrm{Zn}$ ratio in the leaves (Table 4) since its concentration gradually decreased due to $\mathrm{Zn}$ application. In a practical way, the plants showed good growth with a $\mathrm{Mn} / \mathrm{Zn}$ ratio close to 0.95 , while plants with low growth had a ratio close to 3.5 . In addition, other fractions showed interesting results, such as the leaf sheaths $(\mathrm{r}=-0.62)$ and stalk nodes $(\mathrm{r}=0.70)$, with significant correlations for $\mathrm{K} / \mathrm{Zn}$ and $\mathrm{Cu} / \mathrm{Zn}$, and $\mathrm{Mg} / \mathrm{Zn}$, respectively. In time, the soil also differed (Table 4), but only in Ferralsol was there significant correlation for $\mathrm{P} / \mathrm{Zn}, \mathrm{Ca} / \mathrm{Zn}, \mathrm{Cu} / \mathrm{Zn}, \mathrm{Al} / \mathrm{Zn}$ (besides $\mathrm{Fe} / \mathrm{Zn}$ and $\mathrm{Mn} / \mathrm{Zn}$ ), indicating that the changes caused in the ionome of maize leaves due to simultaneous deficiency of $\mathrm{Zn}$ and $\mathrm{P}$ in this soil favored more elements being correlated with the accumulation of dry matter.

\section{CONCLUSIONS}

In $\mathrm{Zn}$-deficient plants we found reduced seedling growth, leaf necrosis (only Cambisol), interveinal chlorosis in new leaves, necrotic spots on the intermediate leaves, internode shortening and darkening of maize stalk nodes. $\mathrm{P}$ deficiency was also found in Ferralsol.

The $\mathrm{Zn}$ deficiency increased $\mathrm{Fe}, \mathrm{Mn}$ and $\mathrm{Al}$ concentrations in all maize plant parts in Cambisol, while in Ferralsol this did not happened for any of the elements analyzed. In both soils the darkening of maize stalk nodes was related to the preferential accumulation of Fe.

Regarding nutritional diagnosis, the $\mathrm{Zn}$ concentrations in the stalk nodes correlate better with dry matter accumulation than in leaves or leaf sheaths. However, using the element/Zn ratios, there is an increase of the correlations using leaves, stalk nodes, and leaf sheaths.

RESUMO: No Brasil, a deficiência de Zn é comum em solos utilizados para o cultivo do milho. Contudo, as mudanças na composição mineral das plantas resultantes da deficiência de Zn têm sido pouco estudadas. Assim, esse estudo objetiva avaliar a relação entre a deficiência de Zn e a composição mineral nas partes de plantas de milho cultivadas em solos contrastantes. $O$ milho foi cultivado em casa de vegetação com doses crescentes de $\mathrm{Zn}(0 ; 0,125 ; 0,25 ; 0,5$ e 1,0 $\mathrm{mg} \mathrm{kg}^{-1}$ ) em dois solos (Latossolo e Cambissolo). Após 60 dias da emergência, as plantas foram fracionadas em raízes, nós do colmo, entrenós do colmo, folhas e bainha das folhas, sendo, posteriormente, determinadas a matéria seca e a composição mineral ( $\mathrm{P}, \mathrm{Ca}, \mathrm{Mg}, \mathrm{K}, \mathrm{Zn}, \mathrm{Fe}, \mathrm{Mn}, \mathrm{Cu}$ e $\mathrm{Al}$ ). Além dos sintomas comumente descritos para deficiência de $\mathrm{Zn}$, constatou-se escurecimento dos nós do colmo (relacionado ao acúmulo preferencial de Fe), sendo que no Latossolo também ocorreu deficiência de P. A deficiência de $\mathrm{Zn}$ favoreceu o aumento das concentrações de $\mathrm{Fe}, \mathrm{Mn}$ e $\mathrm{Al}$ em todas as partes das plantas de milho no Cambissolo, enquanto que no Latossolo isso não ocorreu para nenhum dos elementos analisados. As relações entre os elementos e o $\mathrm{Zn}$ foram mais correlacionadas com a produção de matéria seca do milho que as concentrações de $\mathrm{Zn}$ em folhas, bainhas das folhas e nós do colmo. Pode-se inferir que a acumulação de minerais no milho foi favorecida pela deficiência de Zn, principalmente no Cambissolo.

PALAVRAS-CHAVE: Zea mays L. Acumulação de Fe. Toxidez por metais. Disponibilidade de P. Nós do colmo.

\section{REFERENCES}

ALAM, S. M.; SHEREEN, A. Effect of different levels of zinc and phosphorus on growth and chlorophyll content of wheat. Asian Journal of Plant Sciences, Faisalabad, v. 1, p. 364-366, 2002.

http://dx.doi.org/10.3923/ajps.2002.364.366

ALLOWAY, B. J. Zinc in soils and crop nutrition. 2 ed. Brussels: International Zinc Association \& International Fertilizer Industry Association. 2008. 135p.

BADRI, D. V.; VIVANCO, J. M. Regulation and function of root exudates. Plant, Cell and Environment, Malden, v. 32, n. 6, p. 666-681, 2009. http://dx.doi.org/10.1111/j.1365-3040.2009.01926.x 
BROADLEY, M.; BROWN, P.; CAKMAK, I.; RENGEL, Z.; ZHAO, F. Function of nutrients: micronutrients. In: MARSCHNER, P. (ed.). Marschner's mineral nutrition of higher plants. Ed. 3. San Diego: Elsevier Science, 2012. p. 191-248. http://dx.doi.org/10.1016/B978-0-12-384905-2.00007-8

BROWN, J. C.; HOLMES, R. S. Iron, the limiting element in a chlorosis: Part I. Availability and utilization of iron dependent upon nutrition and plant species. Plant Physiology, Waterbury, v. 30, n. 5, p. 451-457, 1955. http://dx.doi.org/10.1104/pp.30.5.451

CHILIAN, A.; BANCUTA, R. O.; BANCUTA, I.; SETNESCU, R.; ION, R.-M.; RADULESCU, C.; SETNESCU, T.; STIHI, C.; GHEBOIANU, A. I.; CHELARESCU, E. D. Study of the influence of Zn concentration on the absorption and transport of Fe in maize by AAS and EDXRF analysis techniques. Romanian Reports in Physics, v. 67, n. 3, p. 1138-1151, 2015.

GÉRARD, F. Clays minerals, iron/aluminum oxides, and their contribution to phosphate sorption in soils - A myth revisited. Geoderma, v. 262, p. 213-226, 2016. http://dx.doi.org/10.1016/j.geoderma.2015.08.036

HIATT, A. J.; MASSEY, H. F. Zn levels in relation to zinc content and growth of corn. Journal of Agronomy, Madson, v. 50, p. 22-24, 1958.

Food and Agriculture Organization (FAO). World reference base for soil resources. Rome: FAO, 2006. 116 .

KABATA-PENDIAS, A. Trace elements in soils and plants, 4th ed. London, New York: Taylor \& Francis. 2011. $505 \mathrm{p}$.

KANAI, M.; HIRAI, M.; YOSHIBA, M.; TADANO, T.; HIGUCHI, K. Iron deficiency causes zinc excess in Zea mays. Soil Science and Plant Nutrition, Tokyo, v. 55, p. 271-276, 2009. http://dx.doi.org/10.1111/j.17470765.2008.00350.x

MARQUES, J. J.; SCHULZE, D. G.; CURI, N.; MERTZMAN, S. A. Trace element geochemistry in Brazilian Cerrado soils. Geoderma, v. 121, n. 1-2, p. 31-43, 2004. http://dx.doi.org/10.1016/j.geoderma.2003.10.003

MARSCHNER, P. Rhizosphere biology. In: MARSCHNER, P. (ed.). Marschner's mineral nutrition of higher plants. Ed. 3. San Diego: Elsevier Science, 2012. p. 369-388. http://dx.doi.org/10.1016/B978-0-12384905-2.00015-7

MCCLEAN, R. G.; SCHOFIELD, M. A.; KEAN, W. F.; SOMMER, C. V.; ROBERTSON, D. P.; TOTH, D.; GAJDARDZISKA-JOSIFOVSKA, M. Botanical iron minerals: correlation between nanocrystal structure and modes of biological self-assembly. European Journal of Mineralogy, Sttutgart, v. 13, p. 1235-1242, 2001.

NAMBIAR, K. K. M.; MOTIRAMANI, D. P. Tissue Fe/Zn ratio as diagnostic tool for prediction of Zn deficiency in crop plants (in maize). Plant and Soil, Cham, v. 60, p. 357-367, 1981.

http://dx.doi.org/10.1007/BF02149632

PUGA, A. P.; PRADO, R. M.; FONSECA, I. M.; VALE, D. W.; AVALHÃES, C. C. Ways of applying zinc to maize plants growing in Oxisol: effects on the soil, on plant nutrition and on yield. Idesia, Arica, v. 31, n. 3, p. 29-37, 2013. http://dx.doi.org/10.4067/S0718-34292013000300005

RITCHEY, K. D.; COX, F. R; GALRÃO, E. Z.; YOST, R. S. Disponibilidade de Zn para as culturas de milho, sorgo, e soja em Latossolo Vermelho-Escuro argiloso. Pesquisa Agropecuária Brasileira, Brasília, v. 21, n. 3, p. $215-225,1986$.

RODRÍGUEZ, N.; MENÉNDEZ, N.; TORNERO, J.; AMILS, R.; FUENTE, V. Internal iron biomineralization in Imperata cylindrica, a perennial grass: Chemical composition, speciation and localization. The New

Phytologist, v. 165, p. 781-789, 2005. http://dx.doi.org/10.1111/j.1469-8137.2004.01264.x 
RÖMHELD, V. The role of phytosiderophores in acquisition of iron and other micronutrients in graminaceous species: An ecological approach. Plant and Soil, Cham, v. 130, p.127-134, 1991.

http://dx.doi.org/10.1007/BF00011867

SAYRE, J. D. Accumulated iron in the nodes of corn plants. Plant Physiology, Waterbury, v. 5, p. 393-398, 1930. http://dx.doi.org/10.1104/pp.5.3.393

SHANE, M. W.; MCCULLY, M. E.; CANNY, M. J. The vascular system of maize stems revisited: Implications for water transport and xylem safety. Annals of Botany, Oxford, v. 86, p. 245-258, 2000. http://dx.doi.org/10.1006/anbo.2000.1171

United States Department of Agriculture. USDA. Foreign Agricultural Service. World Agricultural Production. Circular Series. June 2016. 27 p. 2016.

VITOSH, M. L.; WARNCKE, D. D.; LUCAS, R. E. Secondary and micronutrients for vegetables and field crops. East Lansing: Michigan State University. 1994. 18p.

WHITE, P. J. Ion uptake mechanisms of individual cells and roots: short-distance transport. In: MARSCHNER, P. (ed.). Marschner's mineral nutrition of higher plants. Ed. 3. Elsevier Science, 2012. p. 7-47. http://dx.doi.org/10.1016/B978-0-12-384905-2.00002-9

ZHAO, A. Q.; BAO, Q. L.; TIAN, X. H.; LU, X. C.; WILIAM, J. G. Combined effect of iron and zinc on micronutrient levels in wheat (Triticum aestivum L.). Journal of Environmental Biology, Vikas Nagar, v. 32, n. 2, p. 235-239, 2011.

ZARE, M.; KHOSHGOFTARMANESH, A. H.; NOROUZI, M.; SCHULIN, R. Critical soil zinc deficiency concentration and tissue iron: zinc ratio as a diagnostic tool for prediction of zinc deficiency in corn. Journal of Plant Nutrition, Florence, v. 32, p. 1983-1993, 2009. http://dx.doi.org/10.1080/01904160903308101 